\title{
Molecular Tectonics: Manganese(II), Copper(II) and Zinc(II) 1D Coordination Polymers Based on Tetramercaptothiacalix[4]arene Bearing Benzoate Coordinating Groups
}

\author{
A. S. Ovsyannikov, ${ }^{\mathrm{a}, \mathrm{c} @ 1}$ S. Ferlay, ${ }^{\mathrm{b} @ 2}$ S. E. Solovieva, ${ }^{\mathrm{a}, \mathrm{c}}$ I. S. Antipin, ${ }^{\mathrm{a}, \mathrm{c}}$ A. I. Konovalov, ${ }^{\mathrm{a}}$ \\ N. Kyritsakas, ${ }^{\text {b }}$ and M. W. Hosseini ${ }^{\text {b@3 }}$ \\ ${ }^{a}$ Kazan Federal University, 420008 Kazan, Russian Federation \\ 'Molecular Tectonics Laboratory, Université de Strasbourg, CNRS, CMC UMR 7140, F-67000 Strasbourg, France \\ 'A.E. Arbuzov Institute of Organic and Physical Chemistry of Kazan Scientific Centre of Russian Academy of Sciences, 420088 \\ Kazan, Russian Federation \\ ${ }^{\circledR 1}$ Corresponding author E-mail: osaalex2007@rambler.ru \\ ${ }^{\circledR 2}$ Corresponding author E-mail: ferlay@unistra.fr \\ ${ }^{\circledR 3}$ Corresponding authorE-mail: hosseini@unistra.fr
}

\begin{abstract}
The combination under mild conditions of the carboxylic appended tetramercaptotetrathiacalix[4]arene (TMTCA) derivative 2 blocked in 1,3-A conformation with acetate salts of octahedral copper(II), manganese(II) and zinc(II), and pyridine, leads to the formation of new $1 D$ coordination polymers in the crystalline state. Whereas for copper(II) and manganese(II) $1 D$ linear coordination polymers are observed, for zinc(II) a zigzag chain has been evidenced.
\end{abstract}

Keywords: Molecular tectonics, coordination polymer, tetramercaptotetrathiacalix[4]arene, carboxylate, transition metals.

\section{Молекулярная тектоника: 1D координационные полимеры на основе бензоатного производного тетрамеркапто- тиакаликс[4]арена и катионов марганца(II), меди(II) и цинка(II)}

\author{
А. С. Овсянников, ${ }^{a, c}$ С. Ферлэй, ${ }^{\mathrm{b} @}$ C. Е. Соловьёва, ${ }^{a, c}$ И. С. Антипин, ${ }^{a, c}$ \\ А. И. Коновалов, ${ }^{a}$ Н. Киритсакас, ${ }^{\mathrm{b}}$ М. В. Хоссейни ${ }^{\mathrm{b}}$ \\ ${ }^{а}$ Казанский федеральный университет, 420008 Казань, Россия \\ bЛаборатория молекулярной тектоники, Страсбургский университет, F-67000 Страсбург, Франция \\ 'Институт органической и физической химии им. А.Е. Арбузова Казанского научного иентра Российской академии \\ наук, 420088 Казань, Россия \\ ${ }^{\circledR 1}$ E-mail: osaalex2007@rambler.ru \\ $\varliminf^{\circledR 2}$ E-mail:ferlay@unistra.fr \\ ${ }^{\circledR 3}$ E-mail: hosseini@unistra.fr
}

\begin{abstract}
Взаимодействие тетрамеркаптотиакаликс[4]арена (ТМТСА) 2 в конформащии 1,3-альтернат, содержащчего карбоксильные группы с октаэдрически координированными катионами меди(II), марганиа(II) и изнка(II) от соответствующих солей ацетатов, в мягких условиях привело кполучению новых 1 кооординационныхполимеров в кристаллической фазе. В то время как в случае катионов меди(II) и марганца(II) наблюдалось образование линейной структуры тубулярного типа, использование катионов марганща позволило синтезировать $1 D$ зигзагоподобную металл-органическую ичепочку.
\end{abstract}

Ключевые слова: Молекулярная тектоника, координационный полимер, тетрамеркаптотетратиакаликс[4]арен, карбоксилат, переходные металлы. 


\section{Introduction}

Coordination Polymers $(\mathrm{CPs})^{[1,2]}$ or coordination networks ${ }^{[3]}$ are periodic architectures generated under selfassembly processes by repetitive coordination bonding between coordinating organic tectons and metal centres or metal complexes offering at least two divergently oriented free coordination sites. These extended networks, owing to precise positioning of molecular components, may find applications, in catalysis, separation and storage or tailored physical properties such as electronic, optic, magnetism or conduction, for example. For some time now, we explore the molecular tectonics approach, ${ }^{[4,5]}$ which deals with the design and formation, in the crystalline phase of molecular networks, in particular, coordination polymers. The formation of the latter class of crystalline material requires combinations of organic tectons with rather restricted conformational space in order to increase the predictability of the architecture and metal centres offering properly disposed coordination sites and geometry.

The calix[4] arene backbone (CA), ${ }^{[6]}$ is particularly interesting for the design of organic coordinating tectons. Owing to its non-planar nature for steric reasons, calix[4] arene adopts four limit conformations (cone $(C)$, partial cone $(C P), 1,2$-alternate and 1,3-alternate) both in solution and in the solid state. Among these conformers, the 1,3-alternate one is of particular interest. Indeed, the latter may be equipped with coordinating sites oriented two by two above and below the main plane of the macrocycle. The same holds for thiacalix[4] arene (TCA) platform, ${ }^{[7]}$ for which all four $\mathrm{CH}_{2}$ groups connecting the phenol moieties are replaced by $\mathrm{S}$ atoms, and for tetramercaptotetrathiacalix [4] arene (TMTCA), ${ }^{[8]}$ for which all four $\mathrm{OH}$ moieties at the lower rim are replaced by $\mathrm{SH}$ groups and all four $\mathrm{CH}_{2}$ groups connecting the phenol moieties are substituted by $\mathrm{S}$ atoms (1, Figure 1).

The formation of coordination networks displaying different dimensionality using tetrasubstituted TMTCA derivatives in 1,3-alternate conformation bearing four nitrile, ${ }^{[9]}$ benzonitrile, ${ }^{[10]}$ carboxylate, ${ }^{[11]}$ pyridyl ${ }^{[12]}$ or pyrazolyl ${ }^{[13]}$ coordinating units, has been already reported by us and others. More recently, the formation of periodic architectures resulting from combinations of three components (TCA derivatives in 1,3-alternate conformation bearing carboxylate moieties, Co(II) salts and bispyridyl auxiliary ligands) has also been reported..$^{[14]}$

Dealing with 1D coordination polymers, based on macrocyclic backbones in 1,3-alternate conformation such as calix[4]arene, ${ }^{[9]}$ thiacalix[4]arene or tetramer-

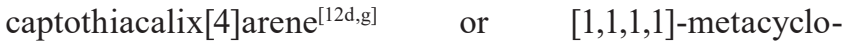
phane, ${ }^{[15]}$ the formation of metallatubulanes type architectures in the presence of $\mathrm{Ag}^{+}$or $\mathrm{Hg}^{2+}$ cations have been reported.

For the formation of $1 \mathrm{D}$ coordination polymers with non-thiophilic transition metals adopting an octahedral coordination geometry, organic tectons based on a rigid backbone and imposed in 1,3-alternate conformation such as CA, TCA and TMTCA bearing four benzoic acid units are candidates of choice. The TMTCA tetrabenzoic acid derivative $^{[16]}$ (2, Figure 1) and its analogue based on TCA backbone ${ }^{[17]}$ have been previously reported.

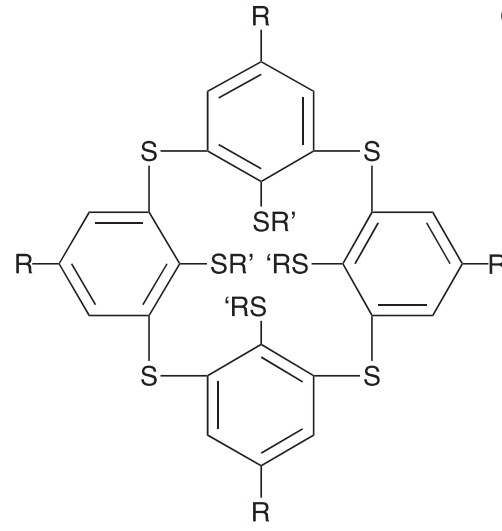

1: $\mathrm{R}=\mathrm{t}-\mathrm{But}^{\prime}, \mathrm{R}^{\prime}=\mathrm{H}$

2: $\mathrm{R}=\mathrm{t}-\mathrm{But}, \mathrm{R}^{\prime}=\mathrm{PhCOOH}$

Figure 1. Tetrathiatetramercaptocalix[4]arene precursor 1 and tetrabenzoic acid appended corresponding tecton in 1,3- $\mathrm{A}$ conformation 2 .

Here, we report on the formation under mild conditions, and structural description of two isostructural linear (2$\mathrm{Cu}_{2}$ and $\left.2-\mathrm{Mn}_{2}\right)$ and a zigzag type (2-Zn) 1-D coordination networks.

\section{Experimental}

All reagents were purchased from commercial sources and used without further purification. The synthesis of $\mathbf{2}$ $(25,26,27,28$-tetra[(4-carboxybenzyl)thio]-5,11,17,23-tetra-tertbutyl-2,8,14,20-tetrathiacalix[4]arene) has been reported. ${ }^{[16]}$

Elemental analyses were performed by the Service de Microanalyses de la Fédération de Recherche Chimie, Université de Strasbourg, Strasbourg, France.

Data for X-ray analysis were collected at 173(2) K on a Bruker APEX8 CCD Diffractometer equipped with an Oxford Cryosystem liquid $\mathrm{N}_{2}$ device, using graphite-monochromated Mo$\mathrm{K} \alpha(\lambda=0.71073 \AA)$ radiation. For all structures, diffraction data were corrected for absorption. Structures were solved using SHELXS-97 and refined by full matrix least-squares on $F^{2}$ using SHELXL-97. The hydrogen atoms were introduced at calculated positions and not refined (riding model) ${ }^{[18]}$ They can be obtained free of charge from the Cambridge Crystallographic Data Centre via www.ccdc. cam.ac.uk/datarequest/cif. CCDC: 1534816-1534818.

Powder diffraction studies (PXRD) diagrams were collected on a Bruker D8 diffractometer using monochromatic $\mathrm{Cu}-\mathrm{K \alpha}$ radiation with a scanning range between 3.8 and $40^{\circ}$ using a scan step size of $2 \% \mathrm{mn}$.

As it was already demonstrated and currently admitted, for all the compounds, discrepancies in intensity between the observed and simulated patterns are due to preferential orientations of the microcrystalline powders.

\section{Crystallisation Conditions}

2-Cu : In a crystallization tube ( $4 \mathrm{~mm}$ diameter, $15 \mathrm{~cm}$ height), a solution of compound $2(5 \mathrm{mg}, 3.8 \mathrm{mmol})$ in pyridine $(1 \mathrm{~mL})$ with five drops of distilled water was layered with a pyridine/ $\mathrm{MeOH}(1 / 1)$ mixture $(1 \mathrm{~mL})$. A solution of $\mathrm{Cu}(\mathrm{OAc})_{2} \cdot \mathrm{H}_{2} \mathrm{O}$ (15 mg, $7.6 \mathrm{mmol})$ in $\mathrm{MeOH}(1 \mathrm{~mL})$ was then carefully added. Slow diffusion at room temperature afforded light blue crystals 
suitable for $\mathrm{X}$-ray diffraction studies after several days. Formula: $\mathrm{C}_{92} \mathrm{H}_{92} \mathrm{Cu}_{2} \mathrm{~N}_{4} \mathrm{O}_{10} \mathrm{~S}_{8} \cdot 2\left(\mathrm{C}_{5} \mathrm{H}_{5} \mathrm{~N}\right)$ Anal. Calcd.: $\mathrm{C}, 62.65 \%$; $\mathrm{H}, 5.26 \%$; N, $4.30 \%$; Found: C, $62.86 \%$; H, $5.30 \%$; N, $4.36 \%$.

2-Mn: To a solution containing compound 2 (5 mg, $4.6 \mathrm{mmol})$ and $\mathrm{Mn}(\mathrm{OAc})_{2} \cdot 4 \mathrm{H}_{2} \mathrm{O}(18 \mathrm{mg}, 7.6 \mathrm{mmol})$ in pyridine $(1 \mathrm{~mL})$, five drops of distilled water were added. The mixture was heated during 2 hours at $80^{\circ} \mathrm{C}$. Upon cooling, colourless crystals suitable for $\mathrm{X}$-ray diffraction studies were obtained. Formula: $\mathrm{C}_{92} \mathrm{H}_{92} \mathrm{Mn}_{2} \mathrm{~N}_{4} \mathrm{O}_{10} \mathrm{~S}_{8} \cdot 2\left(\mathrm{C}_{5} \mathrm{H}_{5} \mathrm{~N}\right)$ Anal. Calcd.: C, $63.21 \%$; H, $5.30 \%$; N, $4.34 \%$; Found: C, $63.35 \%$; H, $5.36 \%$; N, $4.38 \%$.

$2-Z n$ : In a crystallization tube ( $4 \mathrm{~mm}$ diameter, $15 \mathrm{~cm}$ height), a solution of compound $2(5 \mathrm{mg}, 3.8 \mathrm{mmol})$ in pyridine $(1 \mathrm{~mL})$ and five drops of distilled water was layered with a pyridine/ $\mathrm{MeOH}(1 / 1)$ mixture $(1 \mathrm{~mL})$. A solution of $\mathrm{Zn}(\mathrm{OAc})_{2} \cdot 2 \mathrm{H}_{2} \mathrm{O}$ $(16 \mathrm{mg}, 7.6 \mathrm{mmol})$ in $\mathrm{MeOH}(1 \mathrm{~mL})$ was then carefully added. Slow diffusion at room temperature produced colourless crystals suitable for X-ray diffraction studies after several days. Formula: $2\left(\mathrm{C}_{82} \mathrm{H}_{80} \mathrm{~N}_{2} \mathrm{O}_{8} \mathrm{~S}_{8} \mathrm{Zn}\right) \cdot 7\left(\mathrm{C}_{5} \mathrm{H}_{5} \mathrm{~N}\right)$ Anal. Calcd.: C, $65.65 \%$; H, $5.40 \%$; N, $4.23 \%$; Found: C, $65.86 \%$; H, $5.45 \%$; N, $4.27 \%$.

\section{Results and Discussion}

Tecton 2 offers four divergently oriented carboxylic acid moieties, that may be deprotonated into carboxylate coordinating sites. The latter, when combined with acetate salts of transition metals at the oxidation state (II) such as $\mathrm{Cu}, \mathrm{Mn}$ and $\mathrm{Zn}$, should lead to the formation of coordination networks. The nature (connectivity and geometry) of the extended architectures depends on the coordination mode of the carboxylate ligands to the metal centre, and the nature of base used for deprotonation which may be coordinating or non-coordinating. Here we have used pyridine, a coordinating base, to deprotonate the carboxylic acid units. Among many trials, crystals suitable for X-ray diffraction studies could be obtained at room temperature using either slow diffusion of a $\mathrm{MeOH}$ solutions of $\mathrm{Cu}(\mathrm{OAc})_{2} \cdot \mathrm{H}_{2} \mathrm{O}$ or $\mathrm{Zn}(\mathrm{OAc})_{2} \cdot 2 \mathrm{H}_{2} \mathrm{O}$ into a pyridine/MeOH (1/1) solution containing tecton $\mathbf{2}$ in the presence of few drops of water or the slow evaporation of a pyridine solution containing compound $2, \mathrm{Mn}(\mathrm{OAc})_{2} \cdot 4 \mathrm{H}_{2} \mathrm{O}$ and again a few drops of water (see experimental conditions). The use of others salts, other bases and other solvents failed to produce suitable crystals. In all three cases, the formation of 1D coordination networks is observed. The latter architectures are based on coordination bonds between the metal centre, the tecton 2 and pyridine auxiliary ligand. Since, for all three structures, bond distances for tecton $\mathbf{2}$ are similar to those previously observed ${ }^{[16]}$ they are not discussed here.

Two of the used salts $\left(\mathrm{Cu}(\mathrm{OAc})_{2} \cdot \mathrm{H}_{2} \mathrm{O}\right.$ and $\left.\mathrm{Mn}(\mathrm{OAc})_{2} \cdot 4 \mathrm{H}_{2} \mathrm{O}\right)$ afforded isostructural crystals, 2- $\mathrm{Cu}_{2}$ and $2-\mathrm{Mn}_{2}$ (monoclinic $P 2_{1} / \mathrm{n}$ space group), with a $1 / 2$ metal/ligand stoichiometry and the following formula

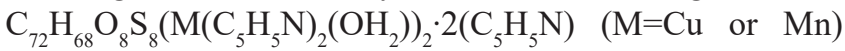
(see Figure 2a). For both $2-\mathrm{Cu}_{2}$ and $2-\mathrm{Mn}_{2}$, one of the tertiobutyl group is found to be disordered.

For both $2-\mathrm{Cu}_{2}$ and $2-\mathrm{Mn}_{2}$, all four carboxylic moieties of $\mathbf{2}$ are fully deprotonated into carboxylate groups, as attested by the equivalent observed $\mathrm{C}-\mathrm{O}$ distances in the 1.226(6)-1.306(6) A range (see Table 1). However, for 2-Zn, the metal/ligand stoichiometry in the crystal (orthorhombic $P b c n$ space group) is found to be $1 / 1$, with the following formula $2\left(\mathrm{C}_{72} \mathrm{H}_{70} \mathrm{O}_{8} \mathrm{~S}_{8} \mathrm{Zn}\left(\mathrm{C}_{5} \mathrm{H}_{5} \mathrm{~N}\right)_{2}\right) \cdot 7\left(\mathrm{C}_{5} \mathrm{H}_{5} \mathrm{~N}\right)$ (see Figure 3a). In marked contrast with $\mathbf{2}-\mathrm{Cu}_{2}$ and $\mathbf{2}-\mathrm{Mn}_{2}$, for $\mathbf{2}-\mathrm{Zn}$, the tecton $\mathbf{2}$ is only partially deprotonated as evidenced by the C-O distances in the 1.237(5)-1.277(5) $\AA$ range for carboxylate groups and in the 1.187(6)-1.311(5) A range for the carboxylic moieties (see Table 1).

For both $1 \mathrm{D}$ isostructural crystals $2-\mathrm{Cu}_{2}$ and $2-\mathrm{Mn}_{2}$, two crystallographically independent divalent metal centres are present. The geometry around the divalent metal centers $(\mathrm{M}=\mathrm{Cu}$ or $\mathrm{Mn})$ is a deformed octahedron with $\mathrm{N}_{2} \mathrm{O}_{4}$ environment, with two nitrogen atoms belonging to two pyridine auxiliary ligands in apical positions, one water molecule and three oxygen atoms from carboxylate units belonging to two different tectons occupying the corners of a square. The metal centers are thus surrounded by two carboxylate groups with one coordinated in a bidentate mode (with one long and one short M-O distances) and the other in a monodentate coordination mode as frequently observed. The $\mathrm{M}-\mathrm{N}, \mathrm{M}-\mathrm{O}_{\text {water }}$ and $\mathrm{M}-\mathrm{O}_{\text {carboxyl }}$ distances are in the 2.020(3)2.057(3), 2.309(3)-2.378(3) and 1.915(3)-2.681(3) $\AA$ range respectively, and the NMN and OMN and OMO angles $(\mathrm{M}=\mathrm{Mn}$ or $\mathrm{Cu})$ are in the 173.06(13)-175.62(12), 84.94(17)-96.89(18) and 54.20(13)-172.83(11) ${ }^{\circ}$ range respectively (see Table 1 for precise values). The oxygen atoms of the uncoordinated carboxylate unit are involved in hydrogen bonding with a water molecule located in cis position of the metal with $\mathrm{d}_{\mathrm{O}-\mathrm{O}}$ distances in the 2.617(4) and 2.673(5) ^̊ range.

The chains are running along the $c$ axis. The 1D arrays are packed in a parallel fashion along the $a$ axis forming a pair of two 1D networks, and parallel along the $b$ axis, as shown in Figure 3b.

The crystal contains also free pyridine molecules with no specific interactions between them and the network. This type of coordination network is analogous to previously reported studies on other macrocycle based tectons, such as metacyclophanes, ${ }^{[15]}$ or calixarenes ${ }^{[9,12 d, g]}$ bearing monodentate binding sites (nitrile or pyridine).

For 2-Zn, again a deformed octahedral $\mathrm{N}_{2} \mathrm{O}_{4}$ environment around the zinc centre with two nitrogen atoms belonging to two coordinated pyridine ligands, in cis disposition, and four oxygen atoms belonging to two carboxylate units, behaving as bidentate ligands, of two different tectons $\mathbf{2}$, is observed. In this case, tecton $\mathbf{2}$ presents two divergently disposed bidentate carboxylate coordinating groups and two divergently disposed non-coordinating carboxylic groups leading to zigzag chains running along the $c$ axis. The $\mathrm{Zn}-\mathrm{N}$ distances are equal to 2.086(4) and 2.099(4) $\AA$, and the $\mathrm{Zn}-\mathrm{O}_{\text {carboxy }}$ are in the 2.010(3)-2.416(3) $\AA$ range. The NZnN angle is equal to $97.73(16)^{\circ}$ and $\mathrm{OZnN}$ and $\mathrm{OZnO}$ angles are in the 95.18(15)-152.38(15) and in the 58.62(12)$157.54(16)^{\circ}$ range respectively (see Table 1 for precise values).

The 1D arrays are packed in a parallel fashion along the $a$ axis forming a pair of two 1D corrugated assemblies and in parallel mode along the $b$ axis (Figure $3 b$ ).

Again, as for $\mathbf{2}-\mathrm{Cu}_{2}$ and $\mathbf{2}-\mathrm{Mn}_{2}$, uncoordinated pyridine molecules are present in the crystal, some of them for H-bonds with oxygen atoms of the carboxylic groups, although carboxylic and carboxylate moieties can be differentiated crystallographically, with $\mathrm{N}-\mathrm{O}$ distances varying between 2.644(6) and 3.572(5) $\AA$. 


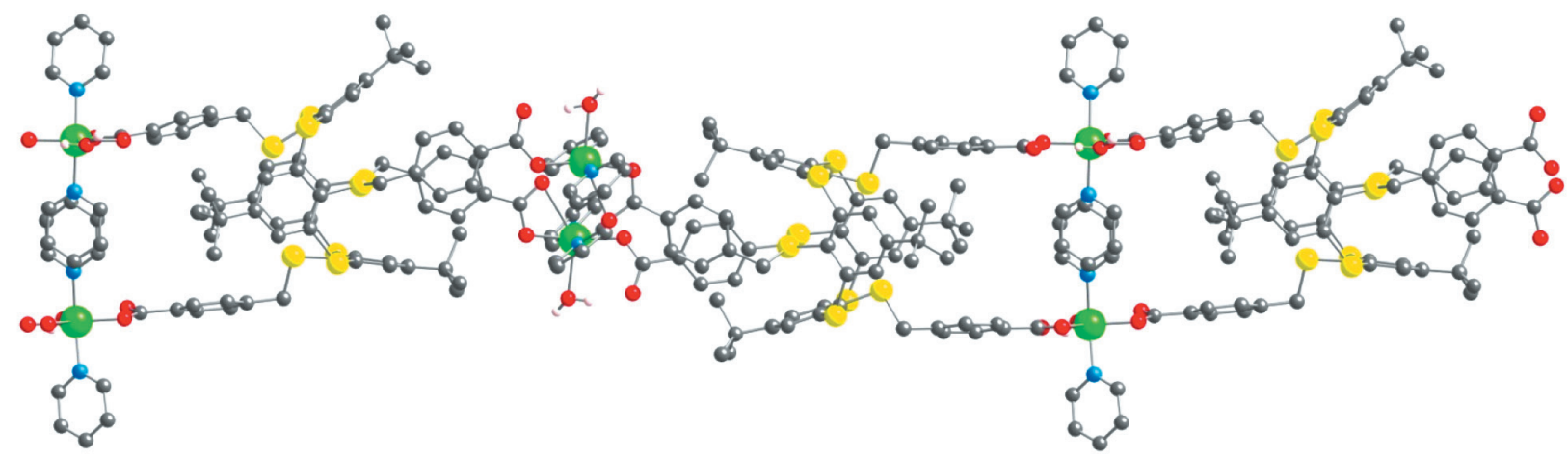

a

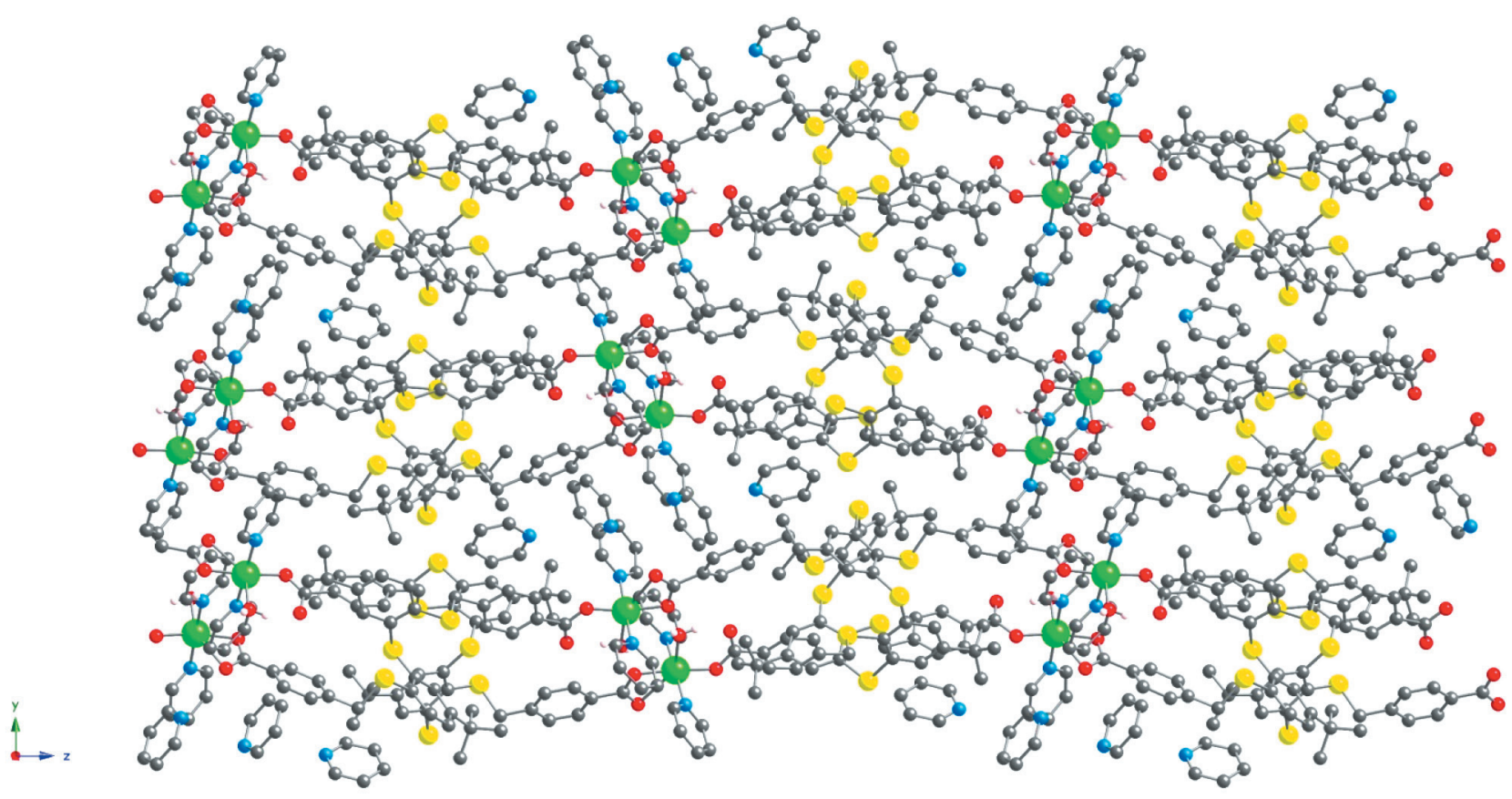

b

Figure 2. A portion of the $1 \mathrm{D}$ crystal structure of $2-\mathrm{Cu}_{2}$ viewed along the $c$ axis (a) and the packing of the chains in the yOz plane (b). Some of the $\mathrm{H}$ atoms and pyridine molecules (a) are omitted for clarity. The disordered tert-butyl groups are not represented. For bond distances and angles see text and Table1.

The connectivity pattern of the 1D coordination polymers has been observed in previous reported coordination networks based on macrocyclic units derived from calixarene, combined essentially with silver cations..$^{[9,11 c, 12 d, 13]}$

The purity of the $2-\mathrm{Cu}_{2}$ and $2-\mathrm{Zn}$ phases was established by PXRD on microcrystalline powder. For $2-\mathrm{Cu}_{2}$, a good match between the observed and simulated patterns from the XRD data was obtained (Figure 4 left). However, for 2-Zn, the quality of the crystalline powder was found to be rather low, nevertheless, similar patterns between the simulated and observed patterns were observed. Unfortunately, 2-Mn, appeared to be unstable, thus, it was not possible to record its PXRD diagram.

\section{Conclusion}

The coordinating behaviour towards some transition metal cations in the oxidation state II ( $\mathrm{Zn}, \mathrm{Cu}, \mathrm{Mn})$ of the rather rigid tecton $\mathbf{2}$, a tetrasubstituted TMTCA derivative, in 1,3- $A$ conformation, bearing four carboxylic acid units, was explored in the solid state. Its combinations, under mild conditions, with acetate salts of octahedral transition metals in the presence of pyridine afforded linear extended one-dimensional coordination networks. Isostructural linear 1D architectures were obtained with copper(II) and manganese(II) $\left(\mathbf{2}-\mathrm{Cu}_{2}\right.$ and $\left.\mathbf{2}-\mathrm{Mn}_{2}\right)$. In both cases, tecton $\mathbf{2}$ is fully deprotonated and a metal/ligand ratio of $2 / 1$ is observed. For $(\mathbf{2}-\mathrm{Zn})$, tecton $\mathbf{2}$ is partially deprotonated and a metal/ ligand ratio of $1 / 1$ is observed. The $1 \mathrm{D}$ network formed is a zigzag type architecture. In all three cases, the coordination sphere around the metals is composed of oxygen atoms belonging to carboxylate coordinating group, acting either as bidentate or monodentate units, and nitrogen atoms belonging to two auxiliary pyridine ligands resulting from competition between pyridine and carboxylate moieties for the binding of the metal centre. It may be worth noting that, whereas for the fully deprotonated tectons $\mathbf{2}$ in $\mathbf{2}-\mathrm{Cu}_{2}$ and $\mathbf{2}-\mathrm{Mn}_{2}$ ), 
Table 1. Main characteristics (distances and angles) for $\mathbf{2}-\mathrm{Mn}_{2}, \mathbf{2}-\mathrm{Cu}_{2}$ and $\mathbf{2}-\mathrm{Zn}$.

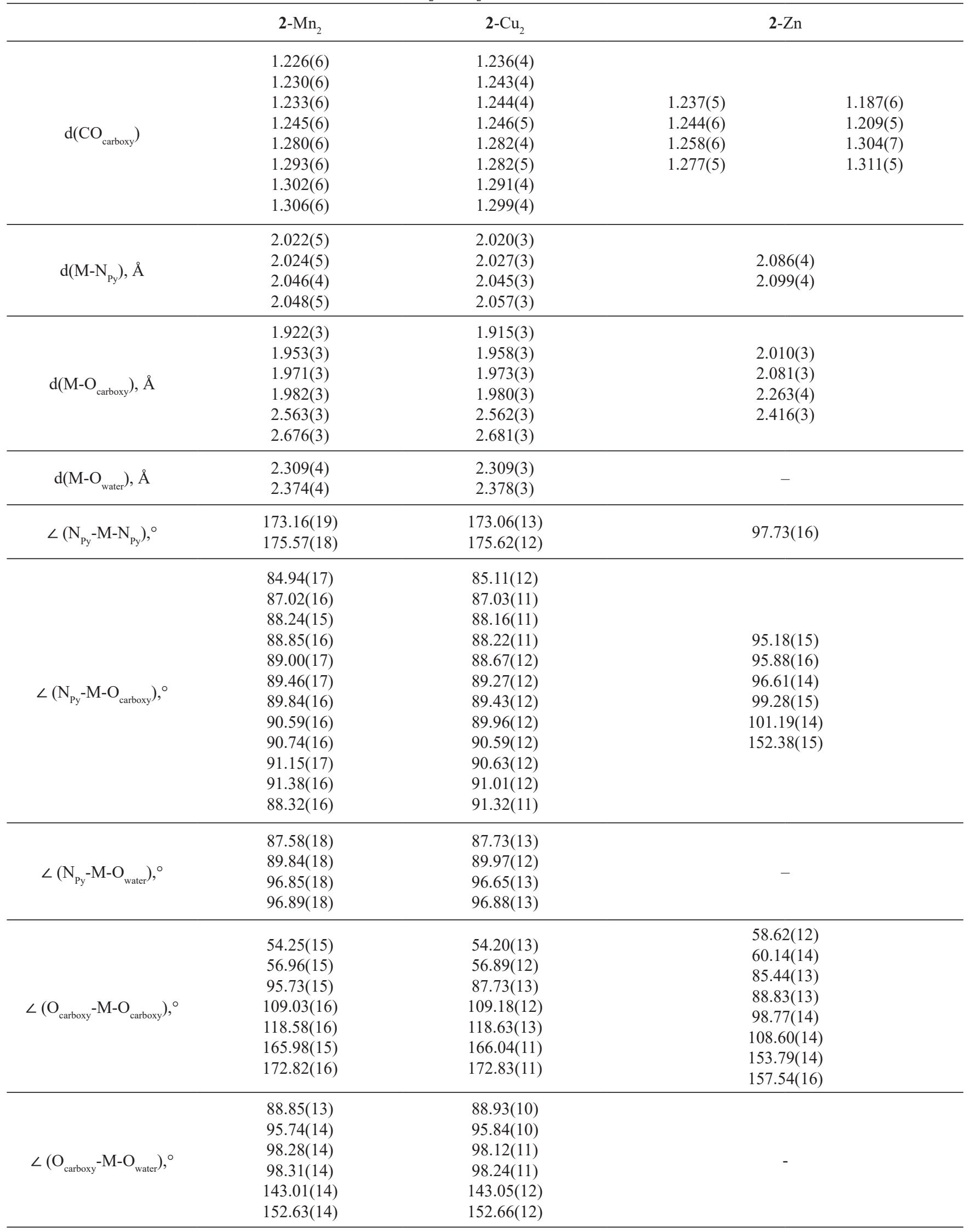




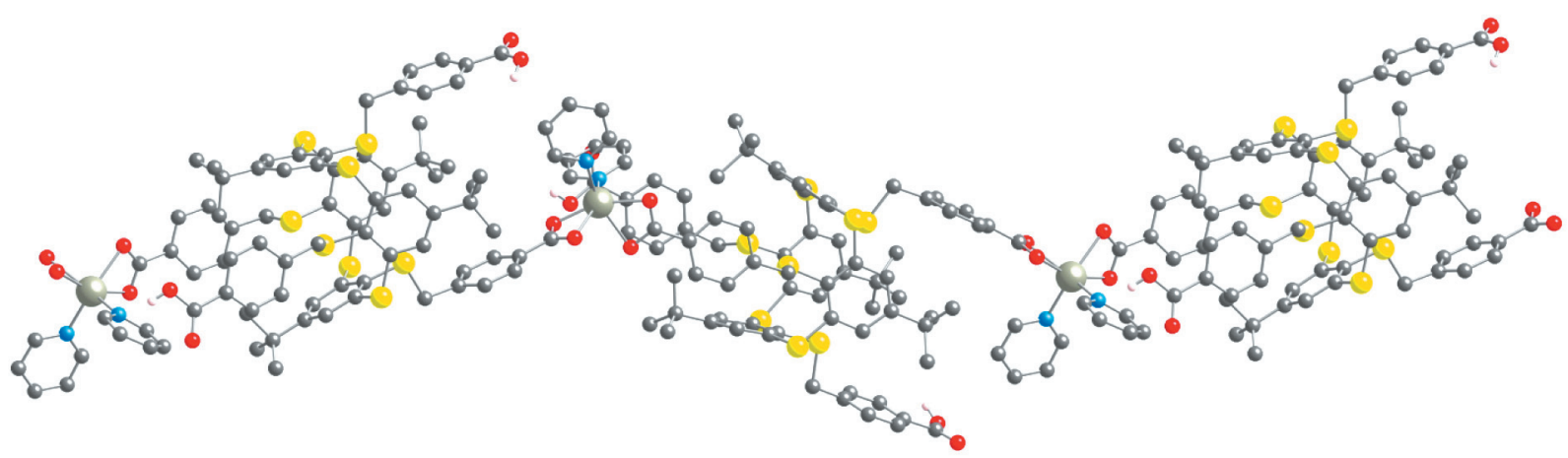

a

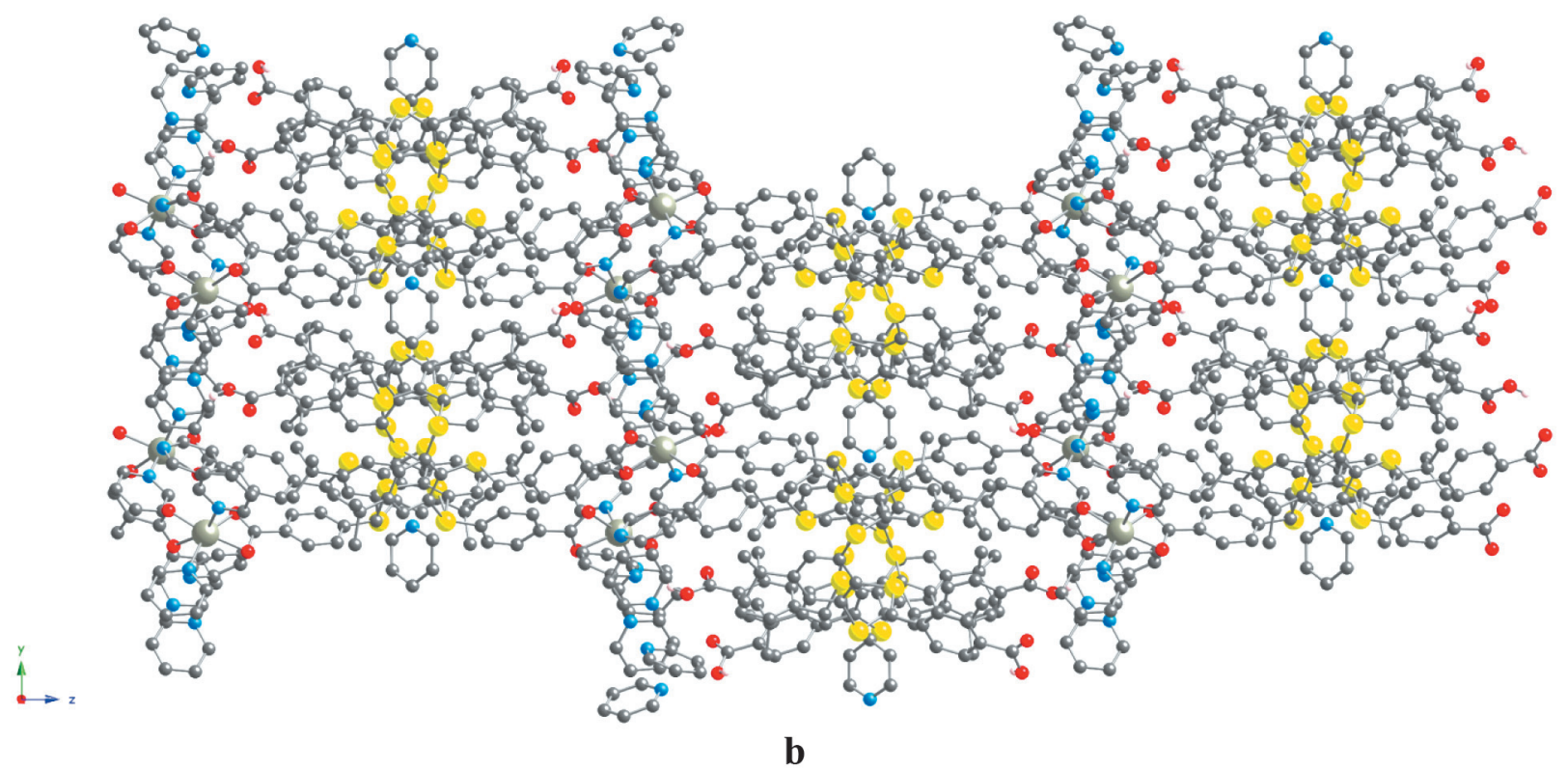

Figure 3. A portion of the 1D crystal structure of 2-Zn viewed along the $c$ axis (a) and the packing of the chains in the yOz plane (b). Some of the $\mathrm{H}$ atoms and pyridine molecules (a) are omitted for clarity. For bond distances and angles see text and Table1.
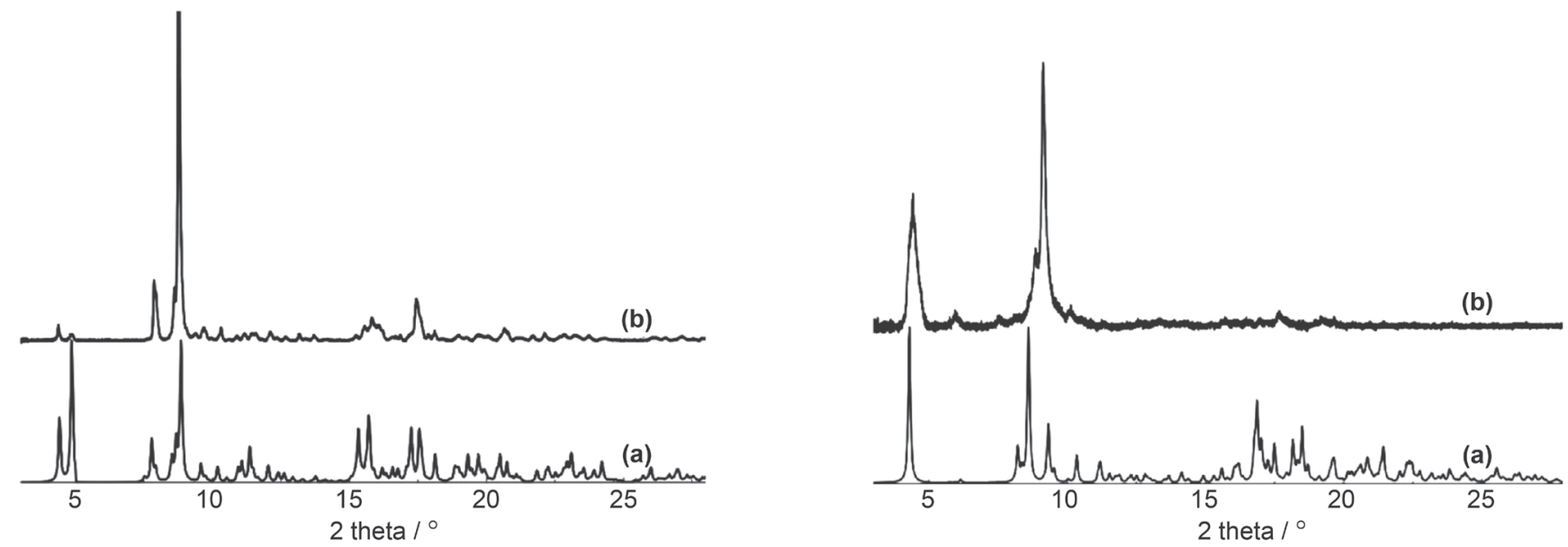

Figure 4. Comparison of the simulated (a) and recorded (b) PXRD patterns for $\mathbf{2}-\mathrm{Cu}_{2}$ (left) and 2- $\mathrm{Zn}$ (right). Discrepancies in intensity between the observed and simulated patterns are due to preferential orientations of the microcrystalline powders. 
the two pyridine moieties occupy the two apical positions on the metal coordination sphere, for the partially deprotonated case $\mathbf{2}-\mathrm{Zn}$, the two pyridine units are cis disposition. In all cases, the sulphur atoms of the macrocyclic backbone are not involved in the binding of the metal centres.

Acknowledgments. This work has been supported by Russian Science Foundation (grant N 15-13-30006). We thank the University of Strasbourg, the CNRS, the Institut Universitaire de France (IUF) and icFRC for financial support.

\section{References}

1. (a) Abrahams B.F., Hoskins B.F., Robson R. J. Am. Chem. Soc. 1991, 113, 3606; (b) Batten S.R., Robson R. Angew. Chem. Int. Ed. 1998, 37, 1460 .

2. (a) Blake A.J., Champness N.R., Hubberstey P., Li W.-S., Withersby M.A., Schröder M. Coord. Chem. Rev. 1999, 193, 117; (b) Moulton B., Zaworotko M.J. Chem. Rev. 2001, 101, 1629; (c) Eddaoudi M., Moler D.B., Li H., Chen B., Reineke T.M., O'Keeffe M., Yaghi O.M. Acc. Chem. Res. 2001, 34, 319; (d) Janiak C. Dalton Trans. 2003, 2781; (e) Carlucci L., Ciani G., Proserpio D.M. Coord. Chem. Rev. 2003, 246, 247; (f) Kitagawa S., Kitaura R., Noro S. Angew. Chem. Int. Ed. 2004, 43, 2334; (g) Férey G., Mellot-Draznieks C., Serre C., Millange F. Acc. Chem. Res. 2005, 38, 218; (h) Bradshaw D., Claridge J.B., Cussen E.J., Prior T.J., Rosseinsky M.J. Acc. Chem. Res. 2005, 38, 273; (i) Kitagawa S., Uemura K. Chem. Soc. Rev. 2005, 34, 109; (j) Maspoch D., Ruiz-Molina D., Veciana J. Chem. Soc. Rev. 2007, 36, 770; (k) Long J.R., Yaghi O.M. Chem. Soc. Rev. 2009, 38, 1213; (1) Janiak C., Vieth J.L. New J. Chem. 2010, 34, 2366; (m) Chem. Soc. Rev. 2009, 38, Themed Issue on Metal-Organic Frameworks; (n) Leong W.L., Vittal J.J. Chem. Rev. 2011, 111, 688; (o) Chem. Rev. 2012, 112, Metal-Organic Frameworks Special Issue.

3. Hosseini M.W. Cryst. Eng. Commun. 2004, 6, 318.

4. (a) Simard M., Su D., Wuest J.D. J. Am. Chem. Soc. 1991, 113, 4696; (b) Mann S. Nature 1993, 365, 499; (c) Wuest J.D. Chem. Commun. 2005, 5830; (d) Hosseini M.W. Chem. Commun. 2005, 5825.

5. Hosseini M.W. Acc. Chem. Res. 2005, 38, 313

6. (a) Gutsche C.D. In: Calixarenes Revised: Monographs in Supramolecular Chemistry. Cambridge: The Royal Society of Chemistry, 1998; (b) Asfari Z., Böhmer V., Harrowfield J., Vicens J. In: Calixarenes 2001. (Asfari Z., Böhmer V., Harrowfield J., Vicens J., Eds.) Dordrecht: Kluwer Academic, 2001; (c) Hosseini M.W. ACS Series 2000, 557, 296.

7. Kumagai H., Hasegawa M., Miyanari S., Sugawa Y., Sato Y., Hori T., Ueda S., Kamiyama H., Miyano S. Tetrahedron Lett. 1997, 38, 3971

8. (a) Rao P., Hosseini M.W., De Cian A., Fischer J. Chem. Commun. 1999, 2169; (b) Akdas H., Graf E., Hosseini M.W., de Cian A., Bilyk A., Skelton B.W., Koutsantonis G.A.,
Murray I., Harrowfield J.M., White A.H. Chem. Commun. 2002, 1042 .

9. (a) Mislin G., Graf E., Hosseini M.W., De Cian A., Kyritsakas N., Fischer J. Chem Commun. 1998, 2545; (b) Kozlova M.N., Ferlay S., Solovieva S.E., Antipin I.S., Konovalov A.I., Kyritsakas N., Hosseini M.W. Dalton Trans. 2007, 5126; (c) Ovsyannikov A., Ferlay S., Solovieva S.E., Antipin I.S., Konovalov A.I., Kyritsakas N., Hosseini M.W. Russ. Chem. Bull. 2015, 64, 1955.

10. Kozlova M.N.K., Ferlay S., Kyritsakas N., Hosseini M.W., Solovieva S.E., Antipin I.S., Konovalov A.I. Chem. Commun. 2009, 2514.

11. (a) Dalgarno S.J., Claudio-Bosque K.M., Warren J.E., Glass T.E., Atwood J.L. Chem. Commun. 2008, 1410; (b) Akdas H., GrafE., Hosseini M.W., De Cian A., Harrowfield J.M. Chem. Commun. 2000, 2219; (c) Park K-M., Lee E., Park C.S., Lee S.S. Inorg. Chem. 2011, 50, 12085; (d) Kim J.-Y., Kim K., Park K-M., Lee S.S. Bull. Korean Chem. Soc. 2014, 35, 289; (e) Lee E., Kim Y., Heo J., Park K-M. Cryst. Growth Des. 2015, 15, 3556; (f) Lee E., Ju H., Moon S.-H., Kang Y., Park K.-M. Bull. Korean Chem. Soc. 2015, 36, 2124.

12. (a) Ovsyannikov A., Lang M.N., Ferlay S., Solovieva S.E., Antipin I.S., Konovalov A.I., Kyritsakas N., Hosseini M.W. Dalton Trans. 2013, 42, 116; (b) Ovsyannikov A., Ferlay S., Solovieva S.E., Antipin I.S., Konovalov A.I., Kyritsakas N., Hosseini M.W. Dalton Trans. 2013, 42, 9946; (c) Ovsyannikov A., Ferlay S., Solovieva S.E., Antipin I.S., Konovalov A.I., Kyritsakas N., Hosseini M.W. Inorg. Chem. 2013, 52, 6776; (d) Ovsyannikov A., Ferlay S., Solovieva S.E., Antipin I.S., Konovalov A.I., Kyritsakas N., Hosseini M.W. Dalton 2014, 43, 158; (e) Ovsyannikov A., Ferlay S., Solovieva S.E., Antipin I.S., Konovalov A.I., Kyritsakas N., Hosseini M.W. Cryst. Eng. Commun. 2014, 16, 3765; (f) Ovsyannikov A., Ferlay S., Solovieva S.E., Antipin I.S., Konovalov A.I., Kyritsakas N., Hosseini M.W. Macroheterocycles 2015, 8(2), 113; (g) Ovsyannikov A., Ferlay S., Solovieva S.E., Antipin I.S., Konovalov A.I., Kyritsakas N., Hosseini M.W. Macroheterocycles 2016, 9, 17.

13. Ovsyannikov A.S., Noamane M.H., Abidi R., Ferlay S., Solovieva S.E., Antipin I.S., Konovalov A.I., Kyritsakas N., Hosseini M.W. Cryst. Eng. Commun. 2016, 18, 691.

14. (a) Kim K., Park S., Park K-M., Lee S.S. Cryst. Growth Des. 2011, 11, 4059; (b) Bew S.P., Burrows A.D., Duren T., Mahon M.F., Moghadam P.Z., Sebestyen V.M., Thurston S. Chem. Commun. 2012, 48, 4824; (c) Zhang Z., Drapailo A., Matvieiev Y., Wojtas L., Zaworotko M.J. Chem. Commun. 2013, 49, 8353.

15. Klein C., Graf E., Hosseini M.W., De Cian A., Fischer J. Chem. Commun. 2000, 239.

16. Ovsyannikov A.S., Lang M., Ferlay S., Solovieva S.E., Antipin I.S., Konovalov A.I., Kyritsakas N., Hosseini M.W. Cryst. Eng. Commun. 2016, 18, 8622.

17. Appelhans D., Stastny V., Komber H., Voigt D., Voit B., Lhotak P., Stibor I. Tetrahedron Lett. 2004, 45, 7145.

18. Sheldrick G.M. Program for Crystal Structure Solution. Göttingen: University of Göttingen, 1997. 